\title{
Relative importance of habitat selection and predation for the distribution of blue crab megalopae and young juveniles
}

\author{
Per-Olav Moksnes ${ }^{1,2, *}{ }^{,}$Kenneth L. Heck Jr. ${ }^{1}$ \\ ${ }^{1}$ Dauphin Island Sea Lab and Department of Marine Sciences, University of South Alabama, \\ 101 Bienville Boulevard, Dauphin Island, Alabama 36528, USA \\ ${ }^{2}$ Present address: Department of Marine Ecology, Göteborg University, Box 461, 40530 Göteborg, Sweden
}

\begin{abstract}
We assessed the relative role of 3 potentially important processes affecting the distribution of young juvenile blue crabs Callinectes sapidus Rathbun: (1) habitat selection at settlement, (2) selection of habitats by dispersing juveniles, and (3) habitat-specific predation rates, using cage experiments. The results suggest that active habitat selection by postlarvae and young juvenile crabs determines the habitat-specific distribution of juvenile blue crabs. Densities of blue crab settlers (megalopae and first instar crabs) in caged habitat patches were high and similar in artificial seagrass, live shoal grass Halodule wrightii, and live oyster habitats (on average 69 to 82 settlers $\mathrm{m}^{-2}$ ), but significantly lower in mud (26 settlers $\left.\mathrm{m}^{-2}\right)$, indicating active selection for any structurally complex habitat at settlement. Second and third instar juvenile blue crabs (J2 and J3 crabs) also colonized the structurally complex habitats in higher numbers (34 to $115 \mathrm{crabs} \mathrm{m}^{-2}$ ), compared to mud (14 crabs $\mathrm{m}^{-2}$ ), demonstrating that young juvenile blue crabs are highly mobile and redistribute soon after metamorphosis. Densities of J2 and J3 blue crabs in uncaged treatments were significantly lower in all habitats than in caged treatments (on average $44 \%$ loss), suggesting high predation mortality. However, the loss of settlers and juvenile crabs was similar in all habitats, and had no significant effect on the juvenile crab distribution. Densities of potential predators were on average 5 times higher in the structurally complex habitats than in mud. An aggregation of predators in the refuge habitats, coupled with a refuge at low prey densities in unstructured habitats, appears to decrease the proximate effect of predation on the distribution of juvenile crabs. Concurrent high settlement of a small xanthid crab (cf. Eurypanopeus sp.) occurred almost exclusively in the oyster habitat, suggesting that species with a limited ability to redistribute after metamorphosis may display a more specific selection of the adult habitat at settlement.
\end{abstract}

KEY WORDS: Post-settlement mortality - Migration - Nursery habitats - Callinectes sapidus · Seagrass $\cdot$ Oysters $\cdot$ Xanthid crab $\cdot$ Palaemonetes sp. $\cdot$ Cage artifacts $\cdot$ Settlement collectors

\section{INTRODUCTION}

In marine benthic organisms with pelagic larvae, settlement and early juvenile stages are a critical phase in the life cycle because of high mortality that can substantially alter their abundance and distribution (for reviews see Ólafsson et al. 1994, Gosselin \& Qian 1997, Hunt \& Scheibling 1997). Young juveniles of motile benthic organisms are often concentrated in structurally complex microhabitats that are thought to provide refuge from predation, e.g. crabs in mussel and seagrass beds (Klein-Breteler 1976, Heck \& Orth 1980), lobsters among macroalgae and cobblestones (Herrnkind \& Butler 1986, Wahle \& Steneck 1991), bivalves in macroalgae (Bayne 1964, Petersen 1984), fish in macroalgae (Carr 1994, Eggleston 1995). Decreased predation mortality in structurally complex habitats in comparison to unstructured sand or mud bottoms has been demonstrated for settling postlarvae of several decapod species in the laboratory (Johns \& 
Mann 1987, Dittel et al. 1996, Moksnes et al. 1997, 1998) and for juvenile stages using tethering techniques (Wilson et al. 1987, Barshaw \& Able 1990, Smith \& Herrnkind 1992, Fernández et al. 1993, Moksnes et al. 1998), and is often suggested as the process responsible for the non-random distribution of juveniles. However, few studies have assessed the direct effect of predation on juvenile distribution, and it remains unclear if differential predation is the direct, i.e. proximate cause of the non-random distribution, or if habitat selection by postlarvae or juveniles, possibly in response to predation, is responsible.

Active habitat selection at settlement has been demonstrated in the laboratory for an increasing number of decapod species with large and strong swimming postlarvae (Botero \& Atema 1982; Herrnkind \& Butler 1986; Fernández et al. 1993, Liu \& Loneragan 1997, Hedvall et al. 1998, Stevens \& Kittaka 1998, van Montfrans et al. 2003). Settling stages of many decapods respond to various chemical and physical cues, including chemical cues from adult conspecifics (Jensen 1989, O'Connor 1991), various habitats (Forward et al. 1994, Wolcott \& De Vries 1994, Brumbaugh \& McConaugha 1995, Welch et al. 1997), and predators (Welch et al. 1997, Diaz et al. 1999), as well as light characteristics (Boudreau et al. 1990) and structural cues (Botero \& Atema 1982, Fernández et al. 1993, Hedvall et al. 1998). These studies suggest that many decapods have highly selective behavior during settlement and that habitat selection by postlarvae may be responsible for the non-random distribution of juvenile stages. However, most studies have been performed in small containers with still water, and less is known about settlement behavior under natural flow conditions in the field and its effect on settlement patterns (but see Eggleston \& Armstrong 1995, Feldman et al. 1997, Palma et al. 1998, Moksnes 2002). Habitat selection by dispersing juveniles may also affect the distribution. Juveniles of many fish and invertebrate species are highly motile and redistribute between habitats after settlement with large effects on the juvenile distribution on both local (Frederick 1997, Moksnes 2002) and regional scales (Beukema \& de Vlas 1989, Etherington \& Eggleston 2000). Few attempts have been made to assess habitat selection at settlement, early post-settlement predation, and habitat selection by juveniles concurrently in the field, and there is a general lack of understanding of how these processes interact and of their relative importance for settlement and post-settlement distribution of young recruits (but see Moksnes 2002).

The blue crab Callinectes sapidus Rathbun is a large, epibenthic omnivore that inhabits soft-bottom coastal areas from Canada to Brazil (Williams 1984), and is one of the most ecologically (e.g. Hines et al. 1990) and commercially important species (e.g. NMFS 1988) in estuaries of the western Atlantic and Gulf of Mexico. Blue crabs have a complex life cycle in which planktonic larvae are advected from estuaries and undergo development in coastal waters. In the Gulf of Mexico, the postlarvae (megalopae) reinvade the estuaries from March to November, with peak settlement occurring in August and September (Stuck \& Perry 1981, Rabalais et al. 1995, Morgan et al. 1996), when high densities of young juvenile crabs are found in shallowwater habitats (Heck et al. 2001, Spitzer et al. 2003). Young juvenile blue crabs $(<20 \mathrm{~mm}$ spine to spine carapace width; CW) are concentrated in structurally complex habitats, and as many as $90 \%$ of the juveniles in a given area may occur in seagrass or submerged marshes (Perry 1975, Heck \& Orth 1980, Weinstein \& Brooks 1983, Heck \& Thoman 1984, Orth \& van Montfrans 1987). In the Chesapeake Bay, the settlement and juvenile habitat for blue crabs is primarily seagrass (i.e. Zostera marina and Ruppia maritima; Heck \& Thoman 1981, Orth \& van Montfrans 1987, Pardieck et al. 1999), whereas, in the Gulf of Mexico, high densities of young juvenile crabs are also found in marsh habitats (Thomas et al. 1990, Wilson et al. 1990, Heck et al. 2001, Spitzer et al. 2003, review by Zimmerman et al. 2000), possibly because marshes on the northeast gulf coast are flooded more or less continuously during summer and fall, due to increased monthly sea levels coupled with southerly winds (Stout 1984). Recent studies have also found high densities of young juvenile blue crabs in macroalgae (Wilson et al. 1990, Epifanio et al. 2003), Eurasian watermilfoil Myriophyllum spicatum, and in shallow detrital habitats (Etherington \& Eggleston 2000) and coarse woody debris (Everett \& Ruiz 1993), demonstrating that juvenile blue crabs use many different habitats and indicating that these habitats may provide important alternative nursery habitats for blue crabs in estuarine systems lacking extensive seagrass beds or flooded marshes. In southern Alabama, the dominant habitats for juvenile blue crabs are salt marshes and submerged aquatic vegetation, which harbor similarly high densities of young juveniles (yearly averages range from 36 to $76 \mathrm{crabs} \mathrm{m}^{-2}$; Heck et al. 2001, Spitzer et al. 2003). Oyster reefs are also an abundant shallow-water habitat in the southern part of Mobile Bay (approximately 1210 ha; Stout 1990) that represents a potential nursery habitat for juvenile blue crabs. However, little is currently known regarding settlement rates, juvenile densities, and survival rates in oyster habitats (but see van Montfrans et al. 2003).

Laboratory and field tethering experiments have demonstrated that predation mortality in juvenile blue crabs is lower in seagrass and algal habitats than on unstructured sand and mud (Wilson et al. 1987, 1990, 
Pile et al. 1996, Moksnes et al. 1997), suggesting that predation may be the proximate cause for the juvenile distribution within shallow nursery areas. However, recent laboratory experiments have demonstrated that blue crab megalopae actively select seagrass over other available habitats (van Montfrans et al. 2003), suggesting that habitat selection at settlement may be responsible for juvenile patterns in the field. Moreover, the distribution of juvenile crabs among 2 seagrass species in Chesapeake Bay differed between size classes (Pardieck et al. 1999), suggesting either an ontogenetic change in habitat preference and redistribution of juvenile crabs, or habitat-specific predation rates. No study to date has concurrently assessed habitat selection of megalopae and juveniles and predation in natural field conditions, and little is known regarding their relative importance for the distribution of juvenile blue crabs.

In the present study we assessed the relative roles of (1) selection of habitats at settlement, (2) habitat selection by dispersing young juveniles, and (3) habitatspecific predation rates as they affect the distribution of young juvenile blue crabs among 4 different microhabitats within a shallow nursery area. These processes were assessed concurrently over 2 to $3 \mathrm{~d}$ using cage techniques. The aim of the study was (1) to test the effect of these 3 processes on the juvenile distribution within nursery areas, (2) to investigate whether blue crab megalopae select 1 specific habitat based on particular cues, or whether any structurally complex habitat is selected for settlement, and (3) to assess the value of live oyster as a settlement habitat and refuge from predation for young juvenile blue crabs. During the study, high settlement of a small xanthid crab (cf.
Eurypanopeus sp.) occurred in the experimental plots. While this species was not the target of the study, we took the opportunity to assess if this xanthid crab, with a less mobile benthic stage, would be more selective of a settlement habitat than the blue crab.

\section{MATERIALS AND METHODS}

The study area. The cage experiment was carried out at Point aux Pins, the eastern tip of a shallow (<2 m), soft-sediment embayment of the Mississippi Sound, Alabama $\left(30^{\circ} 22^{\prime} 28^{\prime \prime} \mathrm{N}, 88^{\circ} 15^{\prime} 22^{\prime \prime} \mathrm{W}\right.$; Fig. 1). This relatively pristine area is affected by a fresh water outflow from the Mobile Bay estuary, and mean summer salinity normally ranges from 20 to 27 parts per thousand (ppt) (Morgan et al. 1996). Summer temperatures in the shallow bay are stable around $30^{\circ} \mathrm{C}$ (Stutes 2000). The tides are diurnal, with semidiurnal tides occurring every 2 wk during minimum tidal amplitudes, and with a mean tidal amplitude of approximately $40 \mathrm{~cm}$. The site is protected from wave exposure, and current speeds are low (1.3 to $4.3 \mathrm{~cm} \mathrm{~s}^{-1}$; Morgan et al. 1996). The shore is lined with marshes, mostly black needlerush Juncus roemerianus, and lesser amounts of smooth cordgrass Spartina alterniflora. In the shallow water $(<0.3 \mathrm{~m}$ mean water level, MWL) outside the march, scattered patches of oysters Crassostrea virginia are found, which are replaced by a more or less continuous seagrass bed in deeper water. In the spring, widgeon grass Ruppia maritima dominates, but is replaced by shoal grass Halodule wrightii in August. At Point aux Pins, average leaf length and density in August and September are

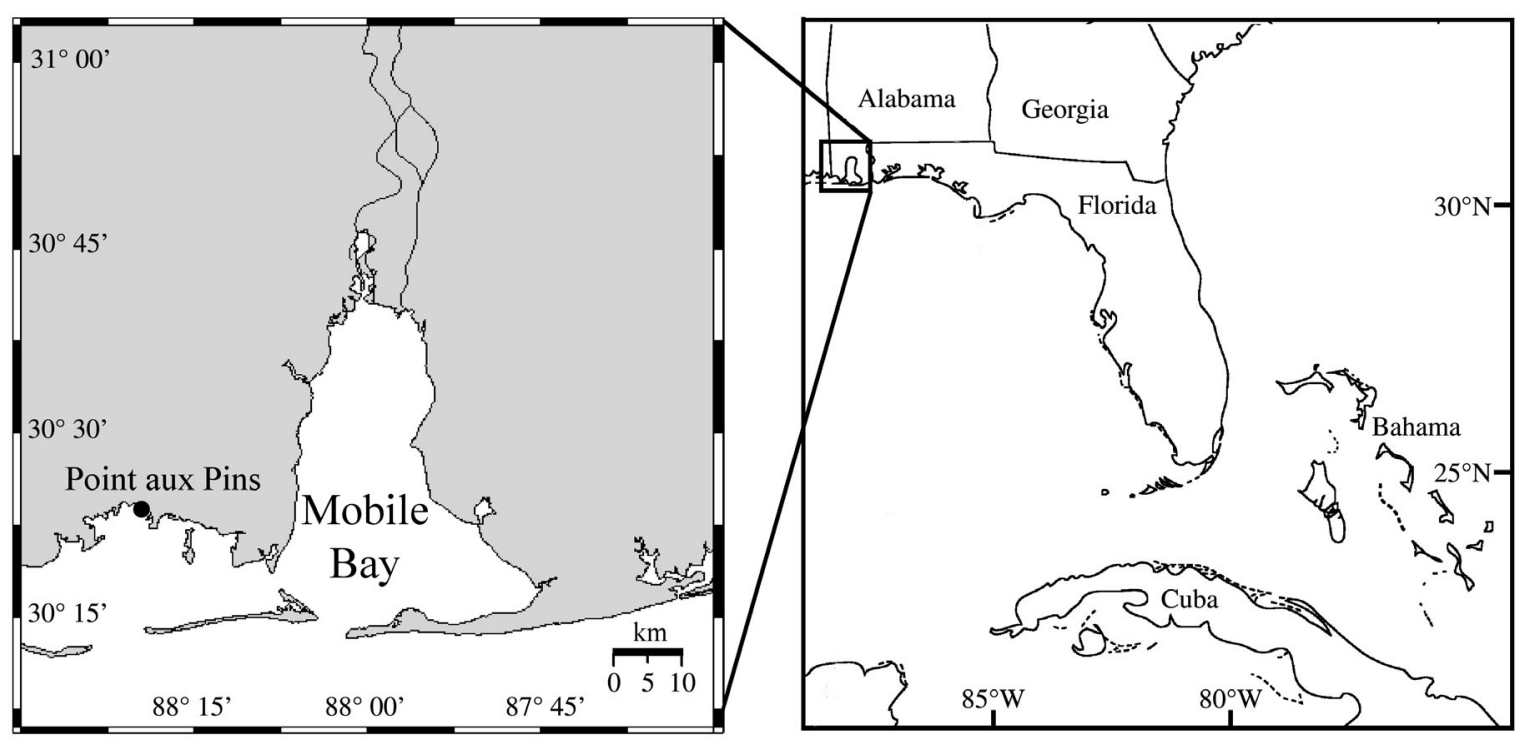

Fig. 1. Study area, Point aux Pins in coastal Alabama, USA 
around $14 \mathrm{~cm}$ and 5000 leaves $\mathrm{m}^{-2}$ (Stutes 2000). Because of high turbidity, seagrass rarely grows deeper than $1 \mathrm{~m}$.

Preliminary studies of cage artifacts. We were concerned that mesh used in the cage experiment could constitute a settlement substrate for blue crab Callinectes sapidus megalopae and function as a filter that either artificially increased or decreased the number of settlers in caged versus uncaged habitats. To study how the behavior of blue crab megalopae and young juvenile crabs was affected by the cage structure, and to test if it affected the colonization rates of habitats inside cages, we performed preliminary laboratory and field experiments.

A laboratory experiment was carried out in August 2002 to observe how megalopae and juvenile crabs behaved when encountering the cage and to test if the cage affected colonization rates of experimental habitats. The experiment was performed in 2 large tanks $\left(2.4 \times 0.45 \mathrm{~m}_{i} 1 \times \mathrm{w}\right)$ made of transparent acrylic sheets. The bottom of each tank was covered with a $2 \mathrm{~cm}$ layer of sieved $(750 \mu \mathrm{m})$, dry beach sand, and tanks were filled to $30 \mathrm{~cm}$ depth with natural seawater (total volume 336 l). A slow, flow-through current $\left(31 \mathrm{~min}^{-1}\right)$ was generated along the tanks by pumping water in at one end of the tank and letting it overflow at the opposite end. A patch of artificial seagrass from the field experiment (see next section for details) was placed in the center of each tank. In 1 randomly chosen tank, 2 sheets $(0.45 \times 0.45 \mathrm{~m})$ of the same $3 \mathrm{~mm}$ mesh net used in the cage experiment were placed vertically on each side of the patch, approximately $1.4 \mathrm{~m}$ apart, partitioning the tank. At the beginning of a trial, approximately 20 blue crab megalopae and 20 second juvenile instar (J2) crabs were introduced at the upstream end of the tank and left for approximately $16 \mathrm{~h}$ overnight. Observations of crab behaviors were made during the first $30 \mathrm{~min}$ and at the end of each trial. Upon termination of a trial, 2 PVC partitions were pushed into the sediment on each side of the patch to separate the seagrass patch from the cage mesh. Crabs were collected with hand nets in each of the 3 resulting sections of the tank and enumerated. Four replicate trials with and without cage mesh were carried out. The proportion of recovered megalopae and J2 crabs found in the seagrass patches were separately tested as dependent variables in 1-factor analysis of variance (ANOVA) models, using cage mesh (absent or present) as the independent variable.

A field experiment was carried out to assess how blue crab megalopae would react to the cage structure in natural flow conditions and if settlement inside experimental cages reflected estimates of settlement on 'standardized' artificial settlement collectors. The collectors consisted of 'hogs-hair' air-conditioner filter material wrapped around a PVC pipe that floated on the surface (see van Montfrans et al. 1995 for details). We used 3 experimental cages with a $3 \mathrm{~mm}$ mesh that allowed blue crab megalopae and first instar juveniles (J1 crabs) to pass through. The cages were placed $30 \mathrm{~m}$ apart at $0.7 \mathrm{~m}$ depth on unvegetated mud bottom and carefully emptied on epifauna prior to the start of each trial (see following section for a detailed description of the cages). A collector was placed inside and next to each cage, and was retrieved after $24 \mathrm{~h}$. Four trials were performed from August 8 to September 30. The number of blue crab settlers (megalopae $+\mathrm{J} 1 \mathrm{crabs}$ ) was analyzed both in a 2-factor mixed-model ANOVA, using treatment (caged and uncaged; fixed factor) and date (random factor) as the independent variables, and in a correlation analysis between paired caged and uncaged collectors. Because the uncaged collectors were floating at the surface approximately $0.7 \mathrm{~m}$ above open mud bottom, we assumed that predation on these collectors would be reduced, and a significant correlation between caged and uncaged collectors would indicate that the cage artifact did not seriously affect settlement in the cages. This experiment also provided an estimate of predation on settlement collectors.

Cage experiment-settlement, predation, and postsettlement movements. To assess the relative importance of habitat selection by postlarvae and juveniles and of predation on the abundance and distribution of juvenile blue crabs, a cage experiment was performed in August and September 2002. The experimental setup consisted of small habitat patches placed in shallow water either with or without cages. We assessed 4 types of habitats (natural shoal grass, artificial seagrass, oysters, and mud) and 2 types of cage treatments (plots with and without predator-exclusion cages). The experiment was repeated twice using 3 and 4 replicates of each cage-habitat combination in the first and second trials, respectively.

The cages were made of polyethylene non-woven fibers with $3 \mathrm{~mm}$ mesh, which measured $1.41 \times 1.41 \times$ $1.25 \mathrm{~m}(\mathrm{l} \times \mathrm{w} \times \mathrm{h})$ with no top or bottom, and were supported by a $9.5 \mathrm{~mm}$ reinforcement bar frame. Pilot studies in the laboratory demonstrated that the mesh allowed blue crab megalopae and juveniles up to approximately $6 \mathrm{~mm}$ spine-to-spine carapace width (CW) to pass through (sideways). Thus, blue crabs up to approximately the third juvenile instar ( $\mathrm{J} 3=4.3$ to $5.8 \mathrm{~mm} \mathrm{CW}$; Millikin \& Williams 1984) could enter the cages, whereas larger crabs, adult grass shrimp Palaemonetes spp. and other potential predators on blue crab megalopae and young juvenile blue crabs were excluded by the mesh. The lower $15 \mathrm{~cm}$ of the cages was buried in sediment, and the upper parts remained above the water surface at all times. The habitats were placed in the center of each cage in a circular patch of approximately $0.17 \mathrm{~m}^{2}$. Thus, the experimental habi- 
tats were separated from the cage walls by at least $1 \mathrm{~m}$. The habitats were: (1) live shoal grass Halodule wrightii, approximately 4000 shoots $\mathrm{m}^{-2}$, of 15 to $20 \mathrm{~cm}$ length, equivalent to natural densities in the study area; Stutes 2000), which was transplanted with intact sediment from grass beds next to the cages and whose epifauna was removed by carefully lifting the grass above the water and shaking the shoots in the water, (2) artificial seagrass mats made from green polypropylene plastic ribbons tied to a plastic mesh at 200 shoots per mat (4 blades per shoot of approximately $6 \mathrm{~mm}$ width and $45 \mathrm{~cm}$ length, equivalent to approximately 1150 shoots $\mathrm{m}^{-2}$ ), (3) oyster clumps of live oysters and oyster shells (approximately 40 live and 40 sets of oyster shells), collected in the area and soaked in freshwater for $30 \mathrm{~min}$, shaken under water and visually inspected to remove epifauna, and placed in a natural upright position, in a tightly packed patch that reached approximately 10 to $15 \mathrm{~cm}$ above the sediment, and (4) bare mud from which structured substrates (e.g. oyster shell and drift algae) were removed as necessary. The artificial grass was used to simulate a wide-leafed seagrass habitat at high natural density (i.e. turtle grass Thalassia testudinum, and eelgrass Zostera marina, the dominant nursery habitats for juvenile blue crabs in other areas) and to assess the importance of physical structure versus chemical cues of the habitat in blue crab settlement. Cages and uncaged plots were located in a single row along the shore, approximately 5 to $10 \mathrm{~m}$ apart. At the start of an experiment, cages were carefully scrubbed to remove fouling organisms and emptied of animals, using handheld dip nets and a suction sampler (cf. Orth \& van Montfrans 1987) driven by a gasoline-powered pump (Honda WB 20X). Experimental treatments were randomly allocated to the plots. Uncaged natural seagrass and mud plots consisted of natural habitat patches of similar size that were emptied of epifauna by hand at the start of a trial.

At the end of a trial, the experimental plots were sampled by placing a $1 \mathrm{~m}$ tall plastic sampling cylinder with a bottom area of $0.20 \mathrm{~m}^{2}$ over the habitat and into the sediment. The water in the cylinder was subsequently evacuated, along with the top $2 \mathrm{~cm}$ of the sediment, into a $500 \mu \mathrm{m}$ mesh collection bag, using the suction sampler. Thus, only the $0.20 \mathrm{~m}^{2}$ plot in the center of the cages was sampled to avoid including animals on the cage structure. The samples were immediately put on ice and later frozen before analysis in the laboratory. The cages were subsequently sampled by dip nets to assess if any predators were present. All epibenthic animals were identified under stereomicroscopes, measured and enumerated. Callinectes sapidus megalopae and juvenile crabs were distinguished from $C$. similis using the criteria established by Stuck \& Perry (1982). In the first trial, the experiment was run for $2 \mathrm{~d}$ (August 13 to 15) and the habitat plots were placed at approximately $0.7 \mathrm{~m}$ depth (MWL), about $50 \mathrm{~m}$ from the marsh edge. Because of problems with low settlement rates and flooding of the cages (see 'Results'), the second trial was run for $3 \mathrm{~d}$ (September 16 to 18$)$, in a shallower location $(0.4 \mathrm{~m}$ depth MWL), approximately 10 to $20 \mathrm{~m}$ from the marsh edge. An independent estimate of blue crab settlement was obtained using standardized artificial settlement collectors, to determine whether settlement in the caged habitats reflected larval supply at the study site. Three replicate collectors were sampled concurrently with each cage trial. Each was immersed for $24 \mathrm{~h}$, floated at the surface next to the cages, and collected during daylight. Salinity and temperature varied between 20 and 24 psu and 29 and $30.5^{\circ} \mathrm{C}$, respectively, during the experimental periods.

The number of blue crab settlers (megalopae and J1 crabs), the proportion of J1 crabs (no. J1 crabs: no. settlers), the number of $\mathrm{J} 2$ and $\mathrm{J} 3$ crabs (4.1 to $6.0 \mathrm{~mm}$ $\mathrm{CW}$ ), and the number of potential predators on blue crab megalopae and J1 to J3 crabs (cannibalistic juvenile blue crabs $>6.0 \mathrm{~mm} \mathrm{CW}$, shrimp $>7 \mathrm{~mm}$ carapace length, fish >15 mm total length; Olmi \& Lipcius 1991, Moksnes et al. 1997) were tested separately as dependent variables in a 2-factor ANOVA model, using habitat (seagrass, artificial grass oyster, and mud) and cage (predator-exclusion, and uncaged plots) as the independent variables. If habitat-specific predation changes the distribution of juvenile crabs, the interaction effects between cage and habitat should be significant. The number of larger juvenile crabs $(>6.0 \mathrm{~mm}$ $\mathrm{CW}$ ) in uncaged habitat plots was analyzed in a 1factor ANOVA, using habitat as the independent variable. Each trial was analyzed separately because of problems with excluding predators in Trial 1 (see 'Results') and because different exposure times and replicates were used in the 2 trials. Before analyses were performed, all data were tested for homoscedasticity with Cochran's C-test (Sokal \& Rohlf 1981) and $\log (x+1)$-transformed to homogenize variances. $A$ posteriori multiple comparison tests were carried out with the Student-Newman-Keuls (SNK) procedure.

\section{RESULTS}

\section{Pilot studies - cage artifacts}

In the laboratory study, average recovery rates of Callinectes sapidus megalopae and J2 crabs were 87 and $99 \%$, respectively. Losses of megalopae were likely due to cannibalism from J2 crabs, since recovery rates of megalopae in tanks without larger conspecifics 
were $100 \%$ ( $\mathrm{n}=10$; P-O. Moksnes unpubl. data). Direct observations of megalopae at the beginning of each laboratory trial showed that some postlarvae swam straight through the $3 \mathrm{~mm}$ mesh, but that most, after encountering the net, either landed on and clung to the mesh, or turned around and swam away from it. Many J2 crabs also hesitated upon encountering the net and dug into the sediment beside it. No megalopae or J2 crabs were observed following the mesh toward the sides of the tank. At the end of the trials only a few megalopae or $\mathrm{J} 2$ crabs were seen on the nets $(<10 \%$ on average).

The proportion of the recovered megalopae found in the artificial seagrass patch was not significantly affected by the presence of a cage $(F=1.92$, df $=1,6$, $\mathrm{p}=0.21$ ), although a trend of lower settlement in the grass was observed in treatments with a cage mesh ( $43 \%$ on average) than in those without $(62 \%)$. The proportion of J2 crabs in seagrass patches did not differ significantly between treatments either $(F=3.25$, $\mathrm{df}=1,6, \mathrm{p}=0.11$ ), although a similar trend of lower densities was observed in patches with a cage mesh (39\% on average) compared to those without (63\%). Although not significantly different, densities were on average 31 and $38 \%$ lower in caged seagrass patches than in uncaged treatments for megalopae and J2 crabs, respectively. The lack of a significant cage effect suggests that the cage artifact is small and should not seriously affect colonization rates in caged habitats. Moreover, the consistent trend of lower crab densities in caged patches indicates that the direction of this artifact is to decrease settlement inside cages in comparison to habitats without cages. Thus, comparisons between uncaged and caged habitats should produce a conservative estimate of predation mortality on juvenile crabs.

In the field experiment with artificial collectors, larval supply varied significantly between 14 and 49 settlers per collector $24 \mathrm{~h}^{-1}$ during the 4 experimental trials, and the number of settlers was significantly higher on caged than uncaged collectors in all trials (Table 1). The difference between caged and uncaged collectors

Table 1. Callinectes sapidus. Field experiment: artificial settlement collectors. A 2-factor ANOVA model testing the number of blue crab settlers (megalopae and first instar juvenile [J1] crabs) as a function of cage treatment and year class. ${ }^{*} \mathrm{p}<0.05 ;{ }^{* * *} \mathrm{p}<0.0001$; not significant (ns): $\mathrm{p}>0.05$

\begin{tabular}{|lrcrc|}
\hline Source of variation & df & Error term & SS & $F$ \\
\hline Cage treatment (A) & 1 & $\mathrm{~A} \times \mathrm{B}$ & 192.7 & $10.3^{*}$ \\
Date (B) & 3 & Residual & 1497.8 & $14.9^{* * * *}$ \\
$\mathrm{~A} \times \mathrm{B}$ & 3 & Residual & 18.8 & $0.2 \mathrm{~ns}$ \\
Residual & 16 & Residual & 100.8 & \\
\hline
\end{tabular}

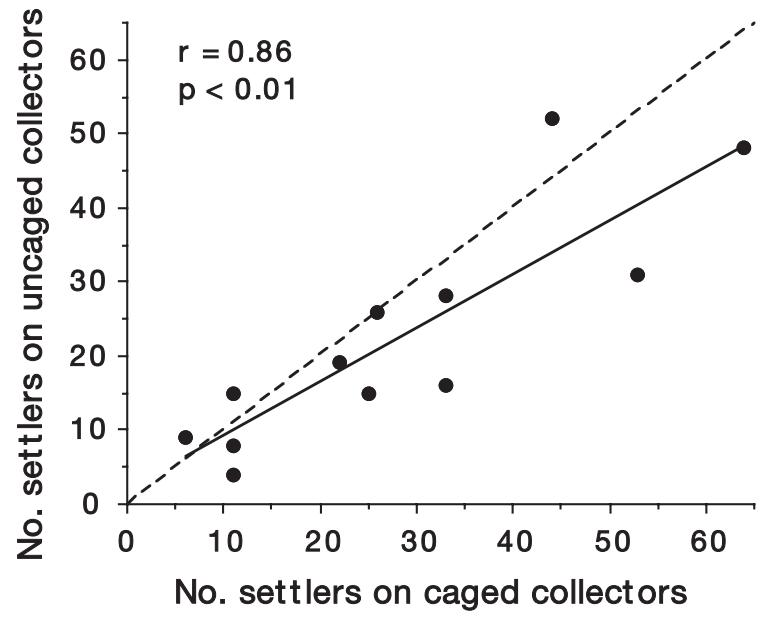

Fig. 2. Callinectes sapidus. Relationship between the numbers of blue crab settlers (megalopae and first instar juvenile [J1] crabs) on artificial settlement collectors provided with predator-exclusion cages and the number of settlers on uncaged collectors. Dotted line: equal settlement on each type of collector

varied between 6 and $34 \%$. The number of settlers on uncaged and caged collectors was correlated significantly and showed a good fit $(\mathrm{df}=10, \mathrm{r}=0.86, \mathrm{p}<0.01$; Fig. 2).

These preliminary results suggest that the mesh tended to decrease settlement inside the experimental cages, but that this artifact was small and constant, so that settlement in caged habitats still represented larval supply to the site. These results also indicate that predation on uncaged collectors in shallow water can be significant (on average $20 \%$ in $24 \mathrm{~h}$ ), but that it did not obscure the temporal settlement pattern. This first assessment of the effect of predation on blue crab settlement on artificial collectors indicates that this common method of estimating larval supply may not be seriously affected by variable predation rates, consistent with the results from a similar study of shore crab (Carcinus maenas) megalopae (Moksnes \& Wennhage 2001).

\section{Cage experiment-settlement, predation, and post-settlement movements}

\section{Predators}

High numbers of potential predators on young blue crabs colonized the uncaged habitat plots in both trials (mainly juvenile blue crabs, grass shrimp, gobiid fish, and, to a lesser extent, juvenile penaeid shrimp). The cage treatment reduced the overall abundance of predators by $>50 \%$ in both trials, but the difference was not significant in the first trial in August, when high water levels flooded the cages the last night of the 
experiment, allowing some potential predators, particularly adult grass shrimp into many cages. In the second trial in September, when no flooding occurred, densities of predators were significantly higher in

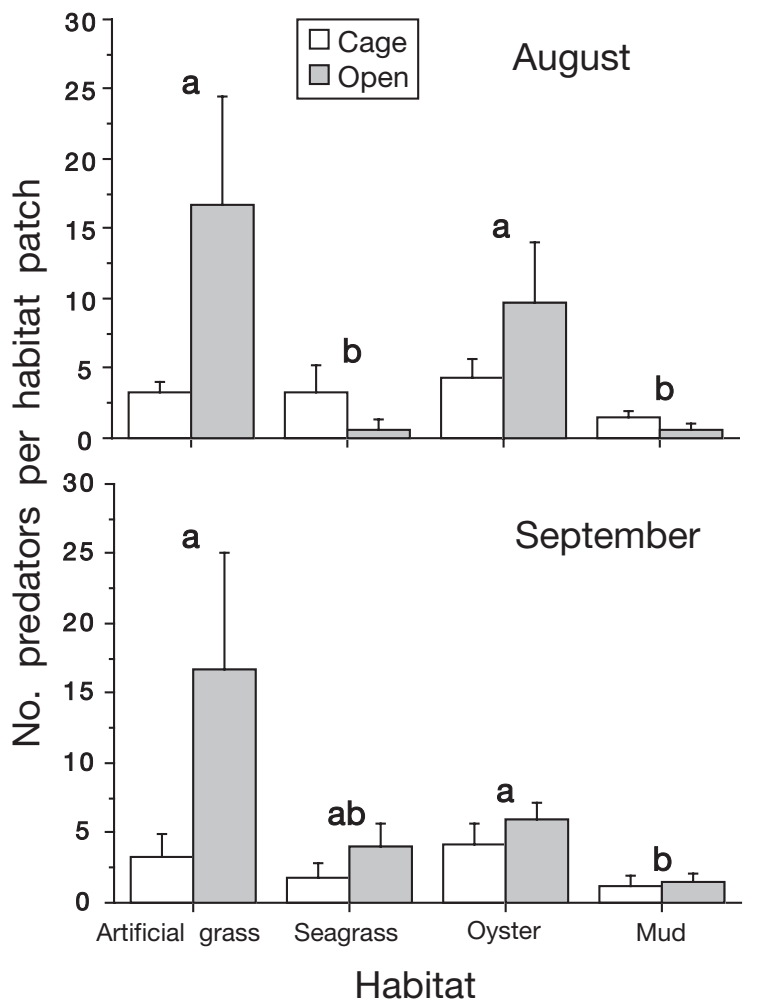

Fig. 3. Mean number of predators (+SE) in 4 different experimental habitat patches (artificial seagrass, live shoal grass, live oyster, and mud) with or without predator-exclusion cages sampled after $48 \mathrm{~h}$ (August) and $72 \mathrm{~h}$ (September). Different letters above bars indicate significantly different means at $\mathrm{p}<0.05$ (SNK test) uncaged treatments in all habitats (Fig. 3, Table 2), although some potential predators were also found in the caged habitats in this trial. The number of predators was significantly higher in artificial seagrass and oyster habitats (on average 11.6 and 3.7 predators per plot, in uncaged and caged treatments, respectively) than in mud (on average 1.2 predators per plot) in both uncaged and caged treatments, in both trials; predator densities in natural seagrass (on average 2.7 predators per plot) were similar to those in mud in the first trial and were not different from the other habitats in the second trial (Fig. 3, Table 2; SNK test at $\mathrm{p}<0.05$ ). The highest density of predators (mainly grass shrimp and juvenile blue crabs) was consistently found in uncaged artificial seagrass (on average 15.8 predators per plot). The interaction effect between cage treatment and habitat was not significant in either trial (Table 2). The low number of potential predators that remained in the caged treatments, despite our efforts to remove them at the start of the experiment, consisted mainly of smaller juvenile blue crabs, grass shrimp, and small gobid fish. Larger crabs and shrimp, and transient fish predators (e.g. Fundulus spp., juvenile sciaenids) that are common in the nursery area were efficiently kept out of the cages. Thus, the small predators inside the cages could potentially prey on blue crab settlers, but probably not on J2 or J3 crabs.

\section{Blue crab settlers}

Densities of blue crab settlers (megalopae + J1 crabs) varied between the 2 trials, but showed a similar pattern on both dates, with lower settlement in mud than in the structurally complex habitats, and with little effect of predation. In August, a low num-

Table 2. Callinectes sapidus. Cage experiment: settlers and second and third instar juvenile (J2, J3) blue crabs. Two-factor ANOVA models testing the number of potential predators on juvenile blue crabs, the number of blue crab settlers, the proportion (prop.) J1 crabs (no. J1 crabs: no. settlers), and the number of J2 and J3 blue crabs as a function of cage treatment and habitat in the August and September trials. All numbers were $\log (x+1)$-transformed, and the proportion was angular-transformed.

${ }^{*} \mathrm{p}<0.05 ;{ }^{* *} \mathrm{p}<0.01 ;{ }^{* * * *} \mathrm{p}<0.0001 ;$ not significant (ns): $\mathrm{p}>0.05$

\begin{tabular}{|c|c|c|c|c|c|c|c|c|c|}
\hline \multirow[t]{2}{*}{ Source of variation } & \multirow[t]{2}{*}{ df } & \multicolumn{2}{|c|}{ No. predators } & \multicolumn{2}{|c|}{ No. settlers } & \multicolumn{2}{|c|}{ Prop. J1 crabs } & \multicolumn{2}{|c|}{ No. J2 and J3 crabs } \\
\hline & & SS & $F$ & SS & $F$ & SS & $F$ & SS & $F$ \\
\hline \multicolumn{10}{|l|}{ August } \\
\hline Cage treatment (A) & 1 & 0.01 & $0.09 \mathrm{~ns}$ & 0.00 & $0.02 \mathrm{~ns}$ & & & 0.04 & $0.47 \mathrm{~ns}$ \\
\hline Habitat (B) & 3 & 1.53 & $6.57^{* *}$ & 1.73 & $5.66^{* *}$ & & & 0.15 & $0.60 \mathrm{~ns}$ \\
\hline $\mathrm{A} \times \mathrm{B}$ & 3 & 0.72 & $3.09 \mathrm{~ns}$ & 0.05 & $0.15 \mathrm{~ns}$ & & & 0.05 & $0.21 \mathrm{~ns}$ \\
\hline Residual & 15 & 1.17 & & 1.53 & & & & 1.22 & \\
\hline \multicolumn{10}{|l|}{ September } \\
\hline Cage treatment $(\mathrm{A})$ & 1 & 0.53 & $5.15^{*}$ & 0.02 & 0.45 & 0.00 & $0.08 \mathrm{~ns}$ & 1.06 & $9.67^{* *}$ \\
\hline Habitat (B) & 3 & 1.32 & $4.30^{*}$ & 1.80 & $11.3^{* * * *}$ & 0.18 & $3.25 \mathrm{~ns}$ & 1.47 & $4.50^{*}$ \\
\hline $\mathrm{A} \times \mathrm{B}$ & 3 & 0.25 & $0.82 \mathrm{~ns}$ & 0.30 & 1.87 & 0.07 & $1.32 \mathrm{~ns}$ & 0.69 & $2.11 \mathrm{~ns}$ \\
\hline Residual & 23 & 2.35 & & 1.22 & & 0.43 & & 2.51 & \\
\hline
\end{tabular}




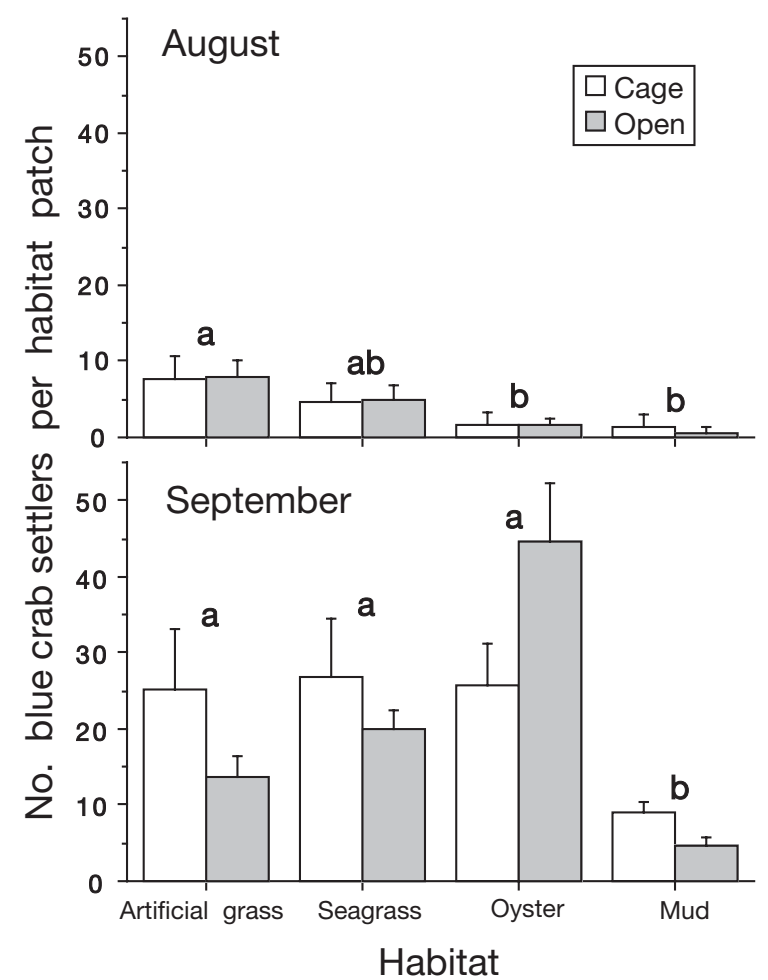

Fig. 4. Callinectes sapidus. Mean number of blue crab settlers $(+\mathrm{SE})$ in 4 different experimental habitat patches with or without predator-exclusion cages in August and September. Different letters above bars: significantly different means at $\mathrm{p}<0.05$ (SNK test)

ber of settlers was collected on the artificial settlement collectors during the $2 \mathrm{~d}$ trial (on average 2.6 per collector $\mathrm{d}^{-1}$ ). The number of settlers was also low in the experimental habitat plots, but differed significantly between habitats in both caged and uncaged treatments, and no effect of cage treatments was seen (Fig. 4, Table 2). Densities of settlers were significantly higher in artificial grass ( 7.8 settlers per plot) than in oyster and mud habitats (1.7 and 1.0 settlers per plot, respectively), while densities in natural seagrass (4.8 settlers per plot) did not differ from those in the other habitats (SNK test at $\mathrm{p}<0.05$ ). Most settlers were $\mathrm{J} 1 \mathrm{crabs}(84 \%)$ at the end of the trial, and the low number of settlers in the sample precluded a test of the proportion of J1 crabs. The flooding and introduction of predators into some cages in August may have decreased our ability to efficiently test the effect of predation, and the results for the cage treatment in August must therefore be interpreted with caution. However, the habitat treatments should not have been affected by this problem. In September, the settlement collectors demonstrated high larval supply of blue crabs during the $3 \mathrm{~d}$ trial (on average 67.9 settlers per collector $\mathrm{d}^{-1}$ ), which was reflected in high

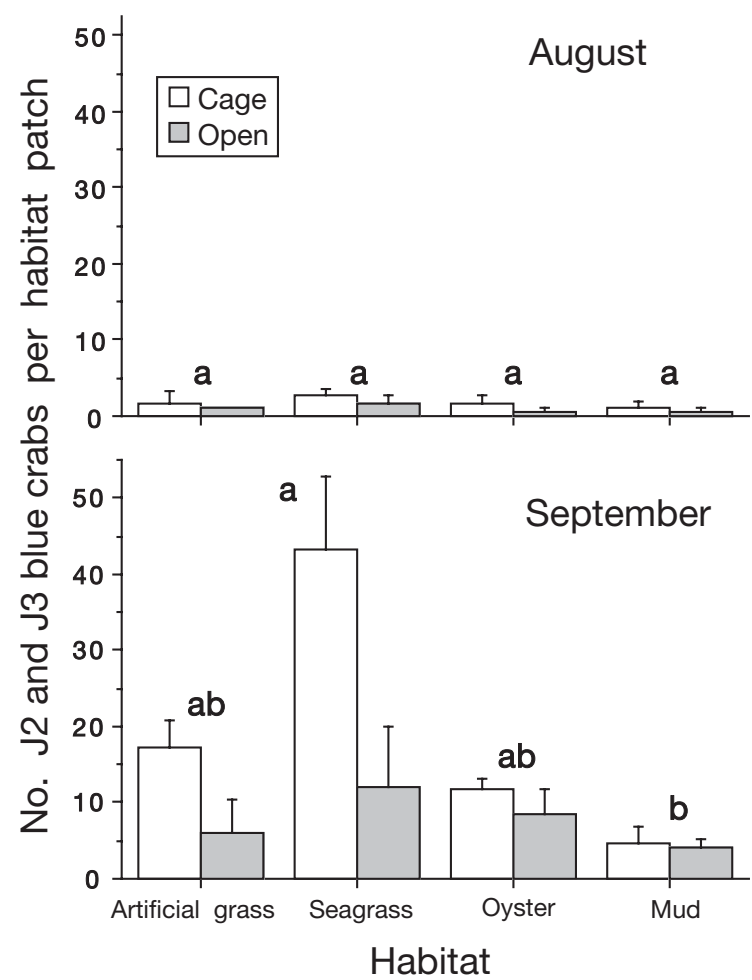

Fig. 5. Callinectes sapidus. Mean number of second and third instar juvenile (J2, J3) crabs (+SE) in 4 different experimental habitat patches with or without predator-exclusion cages in August and September. Different letters above bars: significantly different means at $\mathrm{p}<0.05$ (SNK test)

settlement densities in the habitat plots (up to 44.5 settlers per plot). Densities of settlers were significantly lower in mud (on average 6.9 settlers per plot) than in the 3 structurally complex habitats (20.3 to 35.1 settlers per plot), which did not differ significantly from each other. Lower settlement densities in uncaged compared to caged treatments were observed in all habitats except in the oyster habitat, where the pattern was the opposite (Fig. 4). However, the cage treatment was not found to have any significant effect (Table 2). The proportion of J1 crabs (no. J1 crabs: no settlers) was similar between caged and uncaged treatments ( 85 and $84 \%$, respectively) and between the different habitats ( 74 to $92 \%$ ), and it did not differ significantly between treatments (Table 2).

\section{Juvenile blue crabs}

The numbers of J2 and J3 blue crabs varied between trials, but showed a similar pattern on both dates, with lower densities in mud than in the structurally complex habitats. Densities were consistently lower in uncaged treatments, but losses were similar 


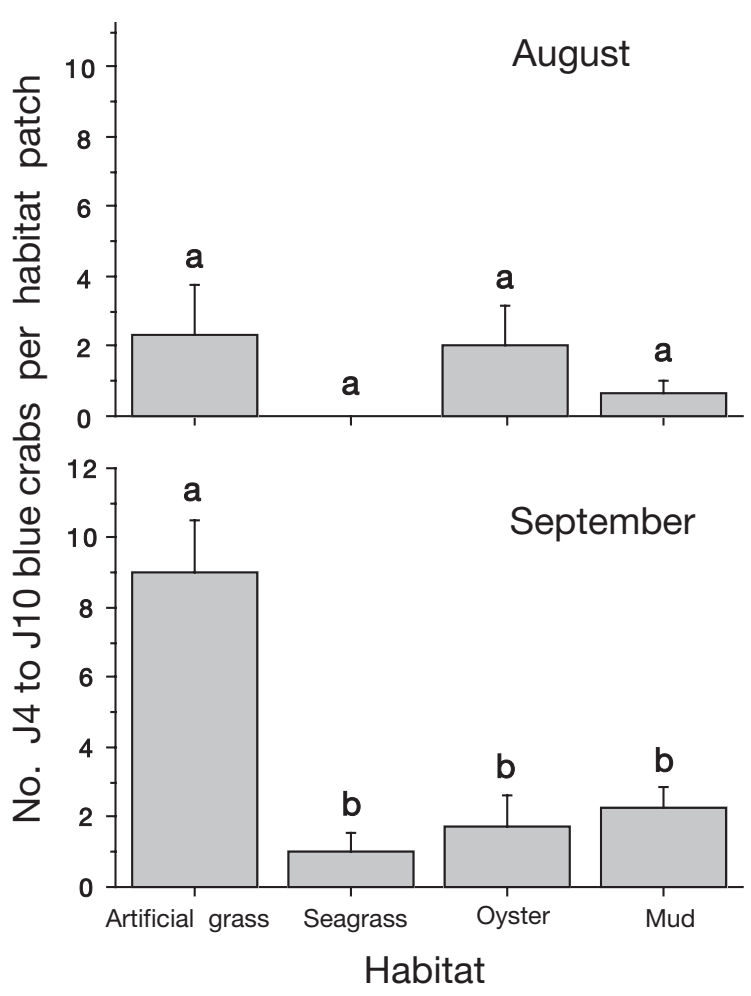

Fig. 6. Callinectes sapidus. Mean number of J4 to J10 (approx. 6.1 to $20.0 \mathrm{~mm} \mathrm{CW}$ ) crabs (+SE) in 4 different experimental habitat patches without predator-exclusion cages in August and September. Different letters above bars: significantly different means at $\mathrm{p}<0.05$ (SNK test)

in all habitats. In August, low numbers of J2 and J3 blue crabs colonized all habitat plots, and densities appeared higher in natural grass (on average 2.2 crabs per plot) than in mud (0.8 crabs per plot), and consistently lower in uncaged than in caged habitats (on average $43 \%$ lower). However, no significant treatment effects were found, possibly due to the overall low densities of crabs (Fig. 5, Table 2). In September, high numbers of J2 and J3 blue crabs colonized the habitat plots (up to 43 crabs per plot), and both the cage and habitat treatments had significant effects on juvenile densities (Fig. 5, Table 2). Significantly higher densities of J2 and J3 crabs were found in all the caged habitats than in the uncaged plots. The proportional difference between caged and uncaged habitats appeared to be largest in natural grass $(72 \%)$ and smallest in mud (16\%), but this difference did not cause a significant cage $\times$ habitat interaction effect $(p=0.13)$. Significantly higher densities of J2 and J3 crabs were found in the natural grass habitat (26.8 crabs per plot) than in mud (3.6 crabs per plot), in both caged and uncaged plots. Densities in artificial grass and in oyster habitats (9.9 and 9.4 crabs per plot, respectively) did not differ significantly from those in the other habitats (SNK test at $\mathrm{p}<0.05)$. The distribution of larger juvenile blue crabs (6.1 to $20.0 \mathrm{~mm} \mathrm{CW}$; approximately J4 to J10 crabs) in uncaged habitat plots differed from the J2 and J3 crab distribution in September, at which time significantly higher densities were collected in the artificial seagrass habitat (9.0 crabs per plot) than in the other habitats ( 1 to 2.3 crabs per plot); these latter habitats did not differ significantly from each other (Fig. 6, Table 3; SNK test at $\mathrm{p}<0.05$ ). In August, densities of J4 to J10 crabs were very low (0 to 2.7 crabs per plot), and no significant habitat effects were found (Fig. 6, Table 3).

\section{Settlement of xanthid crabs}

High settlement of a small panopeid crab (Xanthoidea: Panopeidae; megalopae and J1 crabs 0.7 and $1.2 \mathrm{~mm} \mathrm{CW}$, respectively; cf. Eurypanopeus sp.) occurred in both trials. To assess if the abundance of the xanthid crabs affected the settlement of blue crabs, we carried out a correlation analysis between the number of xanthid and blue crab settlers. The settlement pattern of the xanthid crab was subsequently analyzed using 2-factor ANOVA models to assess if this less mobile species would be more selective of a settlement habitat. No significant correlation was found between xanthid and blue crab settlers $(r=0.005, \mathrm{p}>0.05)$, suggesting that the crabs interacted little at settlement. In contrast to blue crab settlers, xanthid crabs settled almost exclusively in the oyster habitat (on average 71.6 settlers per plot in both trials), which differed significantly from the other habitats (on average 1.8 settlers per plot) on both dates. No significant effects of cage treatments were found, although settlement densities were on average $43 \%$ lower in uncaged oyster habitats than in caged treatments in the 2 trials; no losses were indicated in the other habitats (Fig. 7, Table 4; SNK test at $\mathrm{p}<0.05)$.

Table 3. Callinectes sapidus. Cage experiment: J4 to J10 $(20.0 \mathrm{~mm})$ blue crabs. One-factor ANOVA models testing the number of juvenile blue crabs (6 to $20 \mathrm{~mm} \mathrm{CW}$; $\log (x+1)$ transformed) that colonized uncaged habitat plots as a function of habitat treatments in the August and September trials. ${ }^{* *} \mathrm{p}<0.01$; not significant (ns): $\mathrm{p}>0.05$

\begin{tabular}{|c|c|c|c|c|c|}
\hline \multirow[t]{2}{*}{ Source of variation } & \multirow[t]{2}{*}{$\mathrm{df}$} & \multicolumn{2}{|c|}{ August } & \multicolumn{2}{|c|}{ September } \\
\hline & & SS & $F$ & SS & F \\
\hline Habitat & 3 & 0.39 & 1.42 n.s. & 1.06 & $6.57^{* *}$ \\
\hline Residual & 11 & 0.73 & & 0.59 & \\
\hline
\end{tabular}




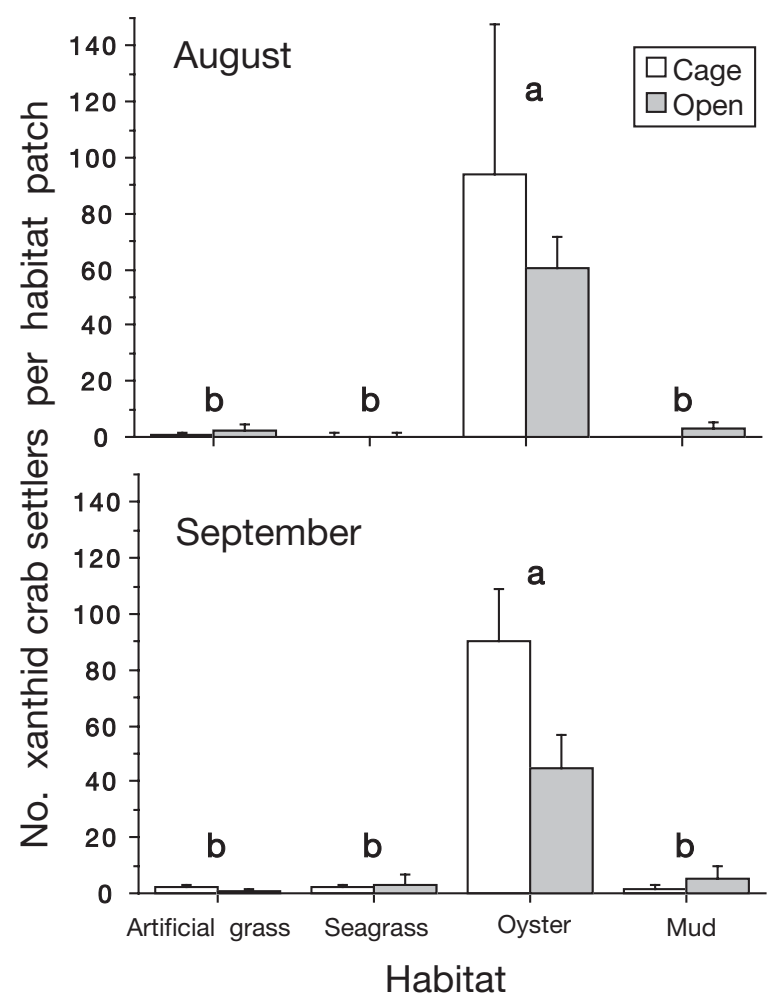

Fig. 7. Xanthid crabs. Mean number of panopeid settlers (+SE) in 4 different experimental habitat patches with or without predator-exclusion cages in August and September. Different letters above bars: significantly different means at $\mathrm{p}<0.05$ (SNK test)

Table 4. Cage experiment: xanthid crabs. Two-factor ANOVA models testing the number of panopeid crab settlers $[\log (x+$ 1)-transformed] as a function of cage treatment and habitat in the August and September trials. No. of settlers was $\log [\log (x$ $+1)+1$ ]-transformed in August. ${ }^{* *} \mathrm{p}<0.01 ;{ }^{* * * *} \mathrm{p}<0.0001$; not significant (ns): $\mathrm{p}>0.05$

\begin{tabular}{|c|c|c|c|c|c|}
\hline \multirow[t]{2}{*}{ Source of variation } & \multirow[t]{2}{*}{$\mathrm{df}$} & \multicolumn{2}{|c|}{ August } & \multicolumn{2}{|c|}{ September } \\
\hline & & SS & $F$ & SS & $F$ \\
\hline Cage treatment (A) & 1 & 0.004 & $1.51 \mathrm{~ns}$ & 0.31 & $2.12 \mathrm{~ns}$ \\
\hline Habitat (B) & 3 & 0.06 & $7.37^{* *}$ & 12.2 & $27.43^{* * * *}$ \\
\hline$A \times B$ & 3 & 0.002 & $0.20 \mathrm{~ns}$ & 0.18 & $0.41 \mathrm{~ns}$ \\
\hline Residual & 15 & 0.04 & & 3.41 & \\
\hline
\end{tabular}

\section{DISCUSSION}

The results demonstrate that both blue crab Callinectes sapidus megalopae and young juveniles actively select several structurally complex habitats over unstructured mud, whereas xanthid settlement occurred almost exclusively in oyster habitats. Predation, even though it was high, had little direct effect on the habitat-specific distribution of postlarvae and juve- niles. We will argue that: (1) settlement behavior in blue crab megalopae has developed mainly in response to the high risk of predation in shallow benthic habitats and that postlarvae actively select any structured habitat that reduces predation mortality during settlement, (2) the high mobility of juvenile blue crabs allows them to redistribute after metamorphosis and select more favorable habitats for juvenile growth, (3) the specific selection of the adult habitat in the xanthid megalopae reflects a limited ability to redistribute after settlement, and (4) predation has little direct (i.e. proximate) effect on the distribution of juvenile crabs due to an aggregation of predators in refuge habitats and a refuge at low prey numbers in unstructured habitats.

\section{Habitat selection}

Blue crab settlers

Settlement of blue crab megalopae in predatorexclusion cages was similarly high in artificial seagrass, live shoal grass, and live oyster habitats (on average 69 to 89 settlers $\mathrm{m}^{-2}$ in the 2 trials), but significantly lower in mud (on average 26 settlers $\mathrm{m}^{-2}$ ). This pattern was clearest in the September trial, when larval supply was high and the exclusion of predators was more successful. Because this settlement pattern occurred in caged habitats where the number of predators was substantially reduced, the result suggests that megalopae actively selected all the structurally complex habitats over mud. Differences in hydrodynamics and passive deposition of larvae (cf. Butman 1987) probably had little effect on the settlement pattern considering the swimming capabilities of blue crab megalopae (up to $13 \mathrm{~cm} \mathrm{~s}^{-1}$; Luckenbach \& Orth 1992) and low current speeds in the area (1.3 to $4.3 \mathrm{~cm} \mathrm{~s}^{-1}$; Morgan et al. 1996) that would allow the postlarvae to maneuver at will. Moreover, low current speeds in combination with the baffling effect of the cage net on the water movements would make the hydrodynamic differences between habitats inside the cages small. Settlement in live oyster clumps varied between trials, but was significantly higher than in mud in September, when very high settlement occurred in the uncaged oyster habitat (on average 223 settlers $\mathrm{m}^{-2}$ ). This result demonstrates that blue crab megalopae can use live oyster habitats as initial settlement sites and that survival during settlement and metamorphosis in oysters can be high despite high numbers of potential predators, suggesting that oyster beds may constitute important nursery habitats for juvenile blue crabs. 
The settlement distribution between habitats did not change in the uncaged treatments despite high densities of potential predators (on average 33 predators $\mathrm{m}^{-2}$; mainly grass shrimp and larger juvenile cannibals), suggesting that predators have little direct effect on settlement patterns. The overall small effect of the cage treatment on settlers was surprising, and may partly be explained by the cage artifact that may have reduced settlement in caged treatments, according to the pilot study. Predation by small shrimp and juvenile crabs that were occasionally found in caged habitats may also have reduced our ability to detect a predation effect, particularly in the August trial, when flooding during the last night of the experiment let low numbers of adult grass shrimp, an efficient predator on blue crab megalopae (Olmi \& Lipcius 1991), into several cages. Colonizing J3 crabs, which can cannibalize megalopae (Moksnes et al. 1997), may also have reduced the number of settlers in the cages. Thus, the apparent greater effect of predation on J2 and J3 crabs than on blue crab settlers was likely due to the fact that predators on the former were more efficiently kept out of the cages. However, concurrent experiments in the bay using the same cages demonstrated high and significant effects of predation on blue crab settlers (up to $70 \%$ in $3 \mathrm{~d}_{\text {; }}$ authors' unpubl. data), as did the pilot study with artificial settlement collectors, suggesting that the predation intensity on blue crab settlers varies temporally.

These results suggest that blue crab megalopae are not specific in their choice of a settlement habitat, but select the first structurally complex habitat they encounter. Moreover, the high settlement in artificial seagrass that was free from epiphytes and epifauna suggests that physical structure was more important than a habitat-specific chemical cue in the habitat choice, and indicates that a settlement habitat is selected for refuge rather than for food. Opportunistic settlement in a refuge habitat may be of selective advantage considering that the risk of predation in shallow nursery areas may be extremely high for a small blue crab megalopa. Although these nursery areas provide favorable temperatures and resources for juvenile growth, predation rates may initially be very high due to the high density of juvenile fish, shrimp, and cannibalistic conspecifics that also aggregate there, as well as high densities of resident small fish (e.g. Fundulus spp.) and grass shrimp Palaemonetes spp., most of which can cause high predation mortality on blue crab settlers (Olmi \& Lipcius 1991, Moksnes et al. 1997, Orth \& van Montfrans 2002). The high risk of predation is supported by field experiments in which predation mortality on tethered young juvenile blue crabs in seagrass and marsh habitats often exceeded $90 \%$ over a period of $24 \mathrm{~h}$ in the study area
(Heck et al. 2001, Spitzer et al. 2003) and $70 \%$ over $24 \mathrm{~h}$ in Chesapeake Bay (Pile et al. 1996). Blue crab megalopae that are carried into shallow-water habitats should therefore avoid unstructured mud and sand habitats, where predation mortality can be even higher (Pile et al. 1996, Heck et al. 2001), and select the first refugeproviding habitat they encounter. Because juvenile blue crabs are good swimmers, they could redistribute to more favorable habitats for juvenile growth after settlement and metamorphosis. Avoidance of low-refuge habitats and selection for a non-specific structurally complex habitat at settlement may be common in highly mobile decapods, such as portunid crabs, that can easily redistribute after settlement. Consistent with these suggestions, shore crab Carcinus maenas megalopae actively select several habitats that provide refuge from predation and redistribute after metamorphosis to preferred mussel habitats (Hedvall et al. 1998, Moksnes et al. 1998, Moksnes 2002).

The hypothesis that blue crabs do not differentiate between different refuge habitats at settlement is supported by most studies that have assessed the distribution of blue crab settlers concurrently in several structurally complex habitats at the same site. For example, in the study area, densities of blue crab settlers are often similarly high in both seagrass (Halodule wrighthii and Ruppia maritima) and marsh habitats (Heck et al. 2001). In a field experiment with uncaged habitats, settlement densities were always very low on open mud, but high and similar in both live seagrass $R$. maritima and the live marsh grasses Spartina alterniflora and Jancus roemerianus (Morgan et al. 1996), similar to the present study. In a similar study, Eggleston et al. (1998) found high settlement in both artificial seagrass and oyster shell habitats in North Carolina, USA. In Chesapeake Bay, blue crab settlers were found principally in seagrass and less often in marsh habitats (Orth \& van Montfrans 1987, 1990), but densities were similar in different seagrass species (e.g. Zostera marina and $R$. maritima; Pardieck et al. 1999). Moreover, the fact that blue crabs settle and metamorphose in high numbers on artificial settlement collectors in many areas in both the Atlantic and the Gulf of Mexico, even when they are located next to large seagrass beds (Rabalais et al. 1995, van Montfrans et al. 1995, Morgan et al. 1996, present study), supports the hypothesis that premolt megalopae select the first refuge habitat they encounter in the nursery area. The only contrasting result is from a field experiment in Chesapeake Bay, in which settlement densities were significantly higher in live $Z$. marina than in live oyster and mud habitats (van Montfrans et al. 2003). However, because predators had access to the habitats, it is not clear whether this pattern was due to habitat selection or habitat-specific predation rates. 
The indiscriminate settlement in any structured habitat is not consistent with suggestions that habitatspecific chemical cues play a dominant role when blue crab megalopae select a settlement habitat. Metamorphosis in blue crab megalopae is accelerated by chemical cues from both eelgrass Zostera marina and salt marsh vegetation (Forward et al. 1994, 1996, Wolcott \& De Vries 1994), and it has been proposed that megalopae use chemical cues to select between settlement habitats (Welch et al. 1997, Forward et al. 2003, van Montfrans et al. 2003). Recent studies indicate that premolt megalopae can display both a positive response to chemical cues from aquatic vegetation (Forward et al. 2003, van Montfrans et al. 2003) and a negative response to chemical cues from various predators (e.g. Paleamonetes pugio, Uca spp., Panopeus herbstii) (Diaz et al. 1999, Forward et al. 2003) and predators and live oysters Crassostrea virginia (Welch et al. 1997). In contrast to these studies, we found very high settlement in live oyster patches in September, despite potential negative cues, and similar high settlement in artificial seagrass and live Halodule wrightii, although the former lacked positive chemical cues and harbored $>25$ times higher densities of Palaemonetes spp. (on average $52 \mathrm{~m}^{-2}$ ) than did $H$. wrightii in uncaged treatments, suggesting that chemical cues do not play a major role in the selection of a settlement habitat in natural field conditions. Although the canopy height and total surface area were greater for artificial seagrass than for the shoal grass patch, which could have confounded an effect of chemical cues, these variables appeared less important, since settlement appeared even higher in the oyster habitat with the smallest vertical profile and surface area. Moreover, the artificial grass and oyster habitats were not selected due to a lack of alternative habitats, since natural grass beds surrounded the experimental plots. Neither were they selected as transient habitats by megalopae not competent to settle (cf. Morgan et al. 1996), since $>84 \%$ of all settlers were J1 crabs when the habitats were sampled after 2 to $3 \mathrm{~d}$, and the proportion of J1 crabs did not differ between habitats. Thus, our results indicate that flow patterns generated by the habitat and/or tactile cues from the physical structure are more important than chemical cues when selecting a settlement habitat. Positive cues from seagrass and marsh habitats may play an important role in accelerating megalopae into premolt, so that metamorphosis can occur quickly once a structurally complex shallow-water habitat is encountered, and they may also be important in the large-scale selection of a settlement area, as indicated by Forward et al. (2003). However, once in a shallow nursery area, the abundance of various positive and negative chemical cues may cancel each other out, making physical cues more important in the selection of microhabitats. Further studies assessing how various chemical cues in different concentrations interact with each other and with physical stimuli in a flow environment are necessary to understand the complex process of habitat selection in blue crab megalopae.

\section{Xanthid settlers}

In contrast to the opportunistic settlement of blue crab megalopae in several structured habitats, settlement of the panopeid megalopae (cf. Eurypanopeus sp.) in the predator-exclusion cages occurred almost exclusively in the oyster habitat, where densities were on average 160 times higher than in the other habitats. These results demonstrate that the panopeid megalopae could efficiently select live oyster habitats for settlement over a scale of 10 s of meters, and suggest that active habitat selection and not predation is the proximate process responsible for the initial benthic distribution of this crab. Differences in hydrodynamics between habitats and passive deposition of larvae probably had little effect on the settlement distribution, considering that $93 \%$ of all settlers were found in the structural habitat with the smallest surface area and lowest vertical profile. The strong response to 1 specific habitat indicates that a chemical cue from the oysters may be involved in the selection process. Chemical cues from adult habitats induced metamorphosis in Panopeus herbstii (Weber \& Epifanio 1996). Several Eurypanopeus species are found exclusively in oyster habitats (Williams 1984, Meyer 1994), and oysters likely also constitute the adult habitat for this unidentified species. The specific selection of the adult habitat in the panopeid megalopae may reflect a limited ability to redistribute after settlement. Eurypanopeus crabs are small and poor swimmers, and much less capable of locating a specific habitat as juveniles in comparison to portunid crabs.

Juvenile blue crabs

High numbers of J2 and J3 blue crabs colonized the predator-exclusion cages in September, resulting in similarly high densities in the structurally complex habitats (on average 28 to $75 \mathrm{crabs} \mathrm{m}^{-2}$ ) and significantly lower densities on mud (on average 13 crabs $\mathrm{m}^{-2}$ ) compared to natural shoal grass. This result demonstrates that young juvenile crabs are highly mobile within nursery areas and redistribute soon after metamorphosis. Because a megalopa cannot molt into a J2 crab during the 2 to $3 \mathrm{~d}$ period of the experiment (Milliken \& Williams 1984), the distribution of J2 and 
J3 crabs was not a result of settlement and subsequent growth. However, because blue crab settlers and J2 and J3 crabs demonstrated similar habitat preferences, the movements by J2 and J3 crabs did not cause a significant change in the initial settlement distribution, although a preference for natural shoal grass was indicated for the latter, possibly reflecting higher availability of food in this habitat that was not cleaned from epiphytes and epifauna prior to the start. The observation that juvenile blue crabs redistribute and actively select structurally complex habitat is consistent with field and laboratory studies demonstrating active habitat selection in juvenile decapods (Herrnkind \& Butler 1986, Fernández et al. 1993, Eggleston \& Armstrong 1995, Liu \& Loneragan 1997, Hedvall et al. 1998, Moksnes 2002).

The distribution of J2 and J3 crabs did not change significantly in the presence of local predators, although significant losses occurred in all uncaged habitats (on average $43 \%$ over 3 d) in September, demonstrating that habitat selection was the dominant process responsible for the distribution of blue crabs. Both predation and emigration in response to predator densities may explain the loss of crabs in the uncaged habitats. However, the latter suggestion is not supported by behavioral studies of young juvenile blue crabs, in which emigration rates from artificial seagrass patches were not affected by the densities of larger cannibalistic crabs, the dominant potential predator found in the uncaged habitats (authors' unpubl. data). Predation mortality is therefore the most plausible explanation for the losses of crabs, and the loss rates correspond well with predation rates from cannibalistic juvenile crabs in laboratory experiments (authors' unpubl. data). Because the preliminary laboratory experiment with $\mathrm{J} 2$ crabs indicated that the cage structure will decrease colonization of caged habitats, the average loss rate of J2 and J3 crabs (equivalent to $17 \% \mathrm{~d}^{-1}$ ) should constitute a conservative estimate of predation mortality for this size class in the nursery area.

The distribution of $\mathrm{J} 4$ to $\mathrm{J} 10$ blue crabs differed from the distribution of settlers and J2 and J3 crabs in the September trial by having low and similar densities in mud, oyster and natural shoal grass habitats (on average 8.3 crabs $\mathrm{m}^{-2}$ ), and significantly higher densities in the artificial seagrass (on average 45 crabs $\mathrm{m}^{-2}$ ). Because this distribution was only assessed in uncaged habitats, since J4 to J10 crabs could not enter the cages, both habitat selection and predation could have caused this non-random distribution. However, considering that predation did not have a significant effect on the distribution of smaller blue crabs, which are thought to be more vulnerable to predation (Pile et al. 1996, Moksnes et al. 1997), habitat selection by colonizing crabs appears to be the most plausible explanation. The difference in habitat selection by J4 to J10 crabs and smaller juveniles may indicate that the requirements of shelter change for crabs $>6 \mathrm{~mm} \mathrm{CW}$, and also that the artificial seagrass habitat was selected because it provided a better refuge from predation for larger juveniles than did the other habitats. The higher canopy, broader blades and larger space between the shoots appeared to be better scaled to shelter the larger juveniles than the thin blades of shoal grass $(<3 \mathrm{~mm}$ width) with very high shoot density. Consistent with these suggestions, juvenile blue crabs $>5 \mathrm{~mm} \mathrm{CW}$ were associated with lower density shoal grass than were smaller juveniles in a similar nursery area in Alabama (Williams et al. 1990). These results provide some support to the ontogenetic shift in habitat use proposed for juvenile blue crabs $>7 \mathrm{~mm} \mathrm{CW}$ in Chesapeake Bay (Pile et al. 1996, Moksnes et al. 1997, Pardieck et al. 1999).

\section{Predation and distribution of juvenile blue crabs}

Although predators caused high losses of young juvenile crabs, predation rates never differed significantly between habitats, suggesting little direct effect of predation on the distribution of crabs. In fact, predation rates on $\mathrm{J} 2$ and $\mathrm{J} 3$ crabs appeared higher in the structurally complex habitats (on average 44 to $55 \%$ loss) than on mud ( $24 \%$ loss). This result is surprising considering that higher predation mortality in unstructured mud and sand habitats is thought to be the major selective force enforcing active habitat selection of structurally complex habitats by postlarvae and juveniles (Wahle \& Steneck 1992, Moksnes et al. 1998). The high losses in the structured habitats may be explained by the fact that larger juvenile cannibals, grass shrimp and small fish predators selected and aggregated in the same habitats as did young juvenile blue crabs, resulting in densities of small predators which were, on average, 5 times higher in the structurally complex habitats than in open mud. Such differences in predator densities may cancel the structural refuge value of the complex habitats. The hypothesis that the density of predators may affect the survival of juvenile crabs is supported by several recent field studies that have demonstrated a negative correlation between the number or survival of young juvenile crabs and the abundance of small invertebrate predators (e.g. J1 blue crabs vs. Palaemonetes spp., Eggleston et al. 1998; survival of tethered J5 to J12 blue crabs vs. larger juvenile crabs, Hovel \& Lipcius 2002; survival of blue crab settlers and J2 and J3 crabs vs. juvenile cannibals, authors' unpubl. data; survival of shore crab 
settlers vs. juvenile cannibals, Moksnes 2004), suggesting that habitat-specific abundance of predators must be taken into account when assessing prey survival in different habitats.

In addition, behavioral responses of the predators to prey desities may also affect predation rates. Recent studies have demonstrated that juvenile crab predators and shrimp can display a Type III functional response to prey densities (cf. Holling 1959) in both structurally complex habitats and open sand (Moksnes et al. 1997, Wennhage 2002, Moksnes 2004), resulting in low prey numbers representing a refuge for prey with a proportionally higher predation mortality at high prey densities. Such behavioral responses may explain why proportional predation mortality of J2 and J3 blue crabs appeared to be highest in natural shoal grass, the habitat with the highest densities of J2 and J3 prey crabs, and lowest in mud where very few prey crabs were found in the caged treatments. A refuge from predation at low prey densities may also explain why the proportional loss of panopeid settlers appeared highest in the preferred oyster habitat. This combination of density-dependent predation rates and aggregations of predators and young juvenile blue crabs in the same habitats may explain why predation rates on tethered blue crabs can be as high in seagrass and marsh habitats as in adjacent unstructured mud or sand habitats (Pile et al. 1996, Heck et al. 2001, Spitzer et al. 2003). Thus, because of the concentration of predators in refuge habitats, and a refuge at low prey densities in unstructured habitats, habitat-specific predation rates may have a smaller proximate effect on the juvenile distribution than generally thought. This suggestion is supported by the few studies that have assessed habitat selection and predation concurrently in benthic decapods and found strong effects of habitat selection on settlement patterns, but little effect of predation (e.g. Dungeness crabs Cancer magister [Eggleston \& Armstrong 1995]; thalassinidean shrimp Neotrypaea californiensis [Feldman et al. 1997]; shore crabs [Hedvall et al. 1998, Moksnes 2002]), which is consistent with the present study. The relative importance of habitat selection and predation has also been assessed in rock crabs Cancer irroratus, but neither factor had a significant effect on juvenile distribution (Palma et al. 1998). In American lobster Homarus americanus habitat selection was suggested to be the proximate cause of the distribution of early benthic American lobster, whereas predation was thought to be the evolutionary process reinforcing the behavior (Wahle \& Steneck 1992).

So why do postlarvae settle preferentially in structurally complex habitats when predation mortality may not be lower there? This apparent paradox may be explained if the dominant predators in nursery areas display a Type III functional response to post- larval prey densities. If most postlarvae did not select habitats, but settled randomly among habitats, the resulting increased prey abundance on mud would increase the predators' foraging activity on postlarvae, and, subsequently, increase the proportional settlement mortality in mud above that in the structurally complex habitats, due to the lack of structural refuges in mud. Many laboratory studies on decapods have demonstrated that when prey densities (and predator densities) are kept equal between habitats, predation mortality on postlarvae and young juveniles is substantially lower in structurally complex habitats than in unstructured mud or sand (Johns \& Mann 1987, Barshaw \& Lavalli 1988, Isaksson et al. 1994, Dittel et al. 1996, Moksnes et al. 1997, 1998, Fernández 1999). Thus, if many postlarvae settled randomly in shallow nursery areas, postlarvae that settle preferentially in refuge habitats would have a selective advantage, retaining the behavior in the population.

In summary, our results suggest that habitat selection by both settlers and young juveniles is responsible for the distribution of juvenile blue crabs within shallow nursery areas. Although predation caused significant mortality on juvenile blue crabs, it had little direct effect on juvenile distribution, probably because the habitat selection and functional response of small predators increased their abundance and capture rates in the refuge habitats. A more specific selection of the adult habitat by xanthid megalopae may reflect a more limited ability to redistribute after settlement, in comparison to blue crabs. The behavioral flexibility of blue crab megalopae, which allowed them to successfully settle and metamorphose in several different structurally complex habitats, would make them well adapted to survive in many different coastal environments and less sensitive to variation in the abundance of any specific nursery habitat. The high settlement and survival in oyster habitats indicate that the nursery value of this and other little studied habitats with high structural complexity may have been underestimated. A better understanding of how these habitats contribute to the recruitment of adult blue crabs may be critical for efficient management of coastal habitats and blue crab fisheries.

Acknowledgements. We thank B. Furman, S. McCall, A. Moesinger, C. Havard and C. Davies for providing excellent assistance during the field experiment, and K. Larsen and R. Heard at the Center for Fisheries Research and Development, Gulf Coast Research Laboratory, Mississippi, for generously helping us with the identification of xanthid crabs. The work was funded by a grant from the Alabama Center for Estuarine Studies (ACES) and by a postdoctoral stipend to P-O.M. from the Hellmuth Hertz' Foundation, the Royal Physiographic Society in Lund, Sweden. 


\section{LITERATURE CITED}

Barshaw DE, Lavalli KL (1988) Predation upon lobster Homarus americanus by cunners Tautogolabrus adspersus and mud crabs Neopanope sayi on three different substrates: eelgrass, mud and rocks. Mar Ecol Prog Ser 48: 119-123

Barshaw DE, Able KW (1990) Tethering as a technique for assessing predation rates in different habitats: an evaluation using juvenile lobster, Homarus americanus. Fish Bull 88:415-417

Bayne BL (1964) Primary and secondary settlement in Mytilus edulis L. (Mollusca). J Anim Ecol 33:513-523

Beukema JJ, de Vlas J (1989) Tidal-current transport of thread-drifting postlarval juveniles of the bivalve Macoma balthica from the Wadden Sea to the North Sea. Mar Ecol Prog Ser 52:193-200

Botero L, Atema J (1982) Behaviour and substrate selection during larval settling in the lobster Homarus americanus. J Crustac Biol 2:59-69

Boudreau B, Bourget E, Simard Y (1990) Benthic invertebrate larval response to substrate characteristics at settlement: shelter preferences of the American lobster Homarus americanus. Mar Biol 106:191-198

Brumbaugh RD, McConaugha JR (1995) Time to metamorphosis of blue crab Callinectes sapidus megalopae: effects of benthic macroalgae. Mar Ecol Prog Ser 129:113-118

Butman CA (1987) Larval settlement of soft-sediment invertebrates: the spatial scales of pattern explained by active habitat selection and the emerging role of hydrodynamical processes. Oceanogr Mar Biol Annu Rev 25:113-165

Carr MH (1994) Effects of macroalgal dynamics on recruitment of a temperate reef fish. Ecology 75:1320-1333

Diaz H, Orihuela B, Forward RB, Rittschof D (1999) Orientation of blue crab, Callinectes sapidus (Rathbun), megalopae: responses to visual and chemical cues. J Exp Mar Biol Ecol 233:25-40

Dittel A, Epifanio CE, Natunewicz C (1996) Predation on mud crab megalopae, Panopeus herbstii H. Milne Edwards: effect of habitat complexity, predator species and postlarval densities. J Exp Mar Biol Ecol 198:191-202

Eggleston DB (1995) Recruitment in Nassau grouper, Epinephelus striatus: post-settlement abundance, microhabitat features, and ontogenetic habitat shifts. Mar Ecol Prog Ser 124:9-22

Eggleston DB, Armstrong DA (1995) Pre- and post-settlement determinants of estuarine Dungeness crab recruitment. Ecol Monogr 65:193-216

Eggleston DB, Etherington LL, Ward EE (1998) Organism response to habitat patchiness: species and habitatdependent recruitment of decapod crustaceans. J Exp Mar Biol Ecol 223:111-132

Epifanio CE, Dittel AI, Rodriguez RA, Targett TE (2003) The role of macroalgal beds as nursery habitat for juvenile blue crabs, Callinectes sapidus. J Shellfish Res 22:881-886

Etherington LL, Eggleston DB (2000) Large-scale blue crab recruitment: linking postlarval transport, post-settlement planktonic dispersal, and multiple nursery habitats. Mar Ecol Prog Ser 204:179-198

Everett RA, Ruiz GM (1993) Coarse woody debris as a refuge from predation in aquatic communities. Oecologia 93: 475-486

Feldman KL, Armstrong DA, Eggleston DB, Dumbauld BR (1997) Effects of substrate selection and post-settlement survival on recruitment success of the thalassinidean shrimp Neotrypaea californiensis to intertidal shell and mud habitats. Mar Ecol Prog Ser 150:121-136
Fernández M (1999) Cannibalism in Dungeness crab Cancer magister: effects of predator-prey size ratio, density, and habitat type. Mar Ecol Prog Ser 182:221-230

Fernández M, Iribarne O, Armstrong D (1993) Habitat selection by young-of-the-year Dungeness crab Cancer magister and predation risk in intertidal habitats. Mar Ecol Prog Ser 92:171-177

Forward RB Jr, Frankel DAZ, Rittschof D (1994) Molting of megalopae from the blue crab Callinectes sapidus: effects of offshore and estuarine cues. Mar Ecol Prog Ser 113:55-59

Forward RB Jr, De Vries MC, Rittschof D, Frankel DAZ, Bischoff JP, Fisher CM, Welch JM (1996) Effects of environmental cues on metamorphosis of the blue crab Callinectes sapidus. Mar Ecol Prog Ser 131:165-177

Forward RB Jr, Tankersley RA, Smith KA, Welch JM (2003) Effects of chemical cues on orientation of the blue crab Callinectes sapidus megalopae in flow: implication for location of nursery areas. Mar Biol 142:747-756

Frederick JL (1997) Post-settlement movement of coral reef fishes and bias in survival estimates. Mar Ecol Prog Ser 150:65-74

Gosselin LA, Qian PE (1997) Juvenile mortality in benthic marine invertebrates. Mar Ecol Prog Ser 146:265-282

Heck KL Jr, Orth RJ (1980) Structural components of eelgrass (Zostera marina) meadows in the lower Chesapeake BayDecapod Crustacea. Estuaries 3:289-295

Heck KL Jr, Thoman TA (1981) Experiments on predatorprey interactions in vegetated aquatic habitats. J Exp Mar Biol Ecol 53:125-134

Heck KL Jr, Thoman TA (1984) The nursery role of seagrass meadows in upper and lower reaches of Chesapeake Bay. Estuaries 7:70-92

Heck KL Jr, Coen LD, Morgan SG (2001) Pre- and post-settlement factors as determinants of juvenile blue crab Callinectes sapidus abundance: results from north-central Gulf of Mexico. Mar Ecol Prog Ser 222:163-176

Hedvall O, Moksnes P-O, Pihl L (1998) Active habitat selection by megalopae and juvenile shore crabs Carcinus maenas: a laboratory study in an annular flume. Hydrobiologia 375/376:89-100

Herrnkind WF, Butler MJ IV (1986) Factors regulating postlarval settlement and juvenile microhabitat use by spiny lobsters Panulirus argus. Mar Ecol Prog Ser 34:23-30

Hines AH, Haddon AM, Wiechert LA (1990) Guild structure and foraging impact of blue crabs and epibenthic fish in a subestuary of Chesapeake Bay. Mar Ecol Prog Ser 67: 105-126

Holling CS (1959) The components of predation as revealed by a study of small-mammal predation of the European pine sawfly. Can Entomol 91:293-320

Hovel KA, Lipcius RN (2002) Effects of seagrass habitat fragmentation on juvenile blue crab survival and abundance. J Exp Mar Biol Ecol 271:75-98

Hunt HL, Scheibling RE (1997) Role of early post-settlement mortality in recruitment of benthic marine invertebrates. Mar Ecol Prog Ser 155:269-301

Isaksson I, Pihl L, van Montfrans J (1994) Eutrophicationrelated changes in macrovegetation and foraging of young cod (Gadus morhua L): a mesocosm experiment. J Exp Mar Biol Ecol 177:203-217

Jensen GC (1989) Gregarious settlement by megalopae of the porcelain crabs Petrolisthes cinctipes (Randall) and P. eriomerus (Stimpson). J Exp Mar Biol Ecol 131:223-231

Johns PM, Mann KH (1987) An experimental investigation of juvenile lobster habitat preference and mortality among habitat of varying structural complexity. J Exp Mar Biol Ecol 109:275-285 
Klein-Breteler WCM (1976) Settlement, growth and production of the shore crab Carcinus maenas on tidal flats in the Dutch Wadden Sea. Neth J Sea Res 10:354-376

Liu H, Loneragan NR (1997) Size and time of day affect the response of postlarvae and early juvenile grooved tiger prawns Penaeus semisulcatus De Haan (Decapoda: Penaeidae) to natural and artificial seagrass in the laboratory. J Exp Mar Biol Ecol 211:263-277

Luckenbach MW, Orth RJ (1992) Swimming velocities and behavior of blue crab (Callinectes sapidus Rathbun) megalopae in still and flowing water. Estuaries 15:186-192

Meyer DL (1994) Habitat partitioning between the xanthid crabs Panopeus herbstii and Eurypanopeus depressus on intertidal oyster reefs (Crassostrea virginica) in southeastern North Carolina. Estuaries 17:674-679

Milliken MR, Williams AB (1984) Synopsis of biological data on blue crab, Callinectes sapidus Rathbun. FAO Fish Synop 38

Moksnes PO (2002) The relative importance of habitatspecific settlement, predation and juvenile dispersal for distribution and abundance of young juvenile shore crabs, Carcinus maenas L. J Exp Mar Biol Ecol 271:41-73

Moksnes PO (2004) Self-regulating mechanisms in cannibalistic populations of juvenile shore crabs, Carcinus maenas. Ecology 85:1343-1354

Moksnes PO, Wennhage H (2001) Methods for estimating decapod larval supply and settlement: importance of larval behavior and development stage. Mar Ecol Prog Ser 209:257-273

Moksnes PO, Lipcius RN, Pihl L, van Montfrans J (1997) Cannibal-prey dynamics in juveniles and postlarvae of the blue crab. J Exp Mar Biol Ecol 215:157-187

Moksnes PO, Pihl L, van Montfrans J (1998) Predation on postlarvae and juveniles of the shore crab Carcinus maenas: importance of shelter, size and cannibalism. Mar Ecol Prog Ser 166:211-225

Morgan SG, Zimmer-Faust RK, Heck KL Jr, Coen LD (1996) Population regulation of blue crabs Callinectes sapidus in the northern Gulf of Mexico: postlarval supply. Mar Ecol Prog Ser 133:73-88

NMFS (National Marine Fisheries Service) (1988) Marine fisheries statistics of the United States. Department of Commerce, NOAA, Washington, DC

O'Connor NJ (1991) Flexibility in timing of the metamorphic molt by fiddler crab Uca pugilator. Mar Ecol Prog Ser 68: $243-247$

Ólafsson EB, Peterson CH, Ambrose WGJ (1994) Does recruitment limitation structure populations and communities of macro-invertebrates in marine soft sediments? The relative significance of pre- and post-settlement process. Annu Rev Oceanogr Mar Biol 32:65-109

Olmi EJ, Lipcius RN (1991) Predation on postlarvae of the blue crab Callinectes sapidus Rathbun by sand shrimp, Crangon septemspinosa Say, and grass shrimp, Palaemonetes pugio Holthuis. J Exp Mar Biol Ecol 151:169-183

Orth RJ, van Montfrans J (1987) Utilization of a seagrass meadow and tidal marsh creek by blue crabs, Callinectes sapidus. I. Seasonal and annual variation in abundance with emphasis on post-settlement juveniles. Mar Ecol Prog Ser 41:283-294

Orth RJ, van Montfrans J (1990) Utilization of a marsh and seagrass habitat by early stages of Callinectes sapidus: a latitudinal perspective. Bull Mar Sci 46:126-144

Orth RJ, van Montfrans J (2002) Habitat quality and prey size as determinants of survival in post-larval and early juvenile instars of the blue crab Callinectes sapidus. Mar Ecol Prog Ser 231:205-213
Palma AT, Wahle RA, Steneck RS (1998) Different early postsettlement strategies between American lobster, Homarus americanus, and rock crabs, Cancer irroratus, in the Gulf of Maine. Mar Ecol Prog Ser 162:215-225

Pardieck RA, Orth RJ, Diaz RJ, Lipcius RN (1999) Ontogenetic changes in habitat use by postlarvae and young juveniles of the blue crab. Mar Ecol Prog Ser 186:227-238

Perry HM (1975) The blue crab fishery in Mississippi. Gulf Res Rep 5:39-57

Petersen JH (1984) Larval settlement behavior in competing species: Mytilus californianus Conrad and $M$. edulis L. J Exp Mar Biol Ecol 82:147-159

Pile AJ, Lipcius RN, van Montfrans J, Orth RJ (1996) Density dependent settler: recruit:juvenile relationships in blue crabs: mechanisms and effects of a tropical storm. Ecol Monogr 66:277-300

Rabalais NN, Burditt FG Jr, Coen LD, Cole BE and 8 others (1995) Settlement of Callinectes sapidus megalopae on artificial collectors in four Gulf of Mexico estuaries. Bull Mar Sci 57:855-876

Smith KN, Herrnkind WF (1992) Predation on early juvenile spiny lobsters, Panulirus argus (Latreille): influence of size and shelter. J Exp Mar Biol Ecol 157:3-18

Sokal RR, Rohlf FJ (1981) Biometry: The principles and practice of statistics in biological research. WH Freeman, New York

Spitzer PM, Heck KL Jr, Valentine JF (2003) Then and now: a comparison of patterns in blue crab post-larval abundance and post-settlement mortality during the early and late 1990s in the Mobile system. Bull Mar Sci 72:435-452

Stevens BG, Kittaka J (1998) Postlarval settling behavior, substrate preference, and time to metamorphosis for red king crab Paralithodes camtschaticus. Mar Ecol Prog Ser 167: 197-206

Stout JP (1984) The ecology of irregularly flooded salt marshes of the northeastern Gulf of Mexico: a community profile. Biol Report 85(7.1), Fish and Wildlife Service Minerals Management Service

Stout JP (1990) Estuarine habitats. In: Mobile Bay: issues, resources, status, and management. Estuary of the Month Seminar Ser No. 15, MASGP-89-023, NOAA, Washington, DC, p 63-89

Stuck KC, Perry HM (1981) Observations on the distribution and seasonality of portunid megalopae in Mississippi coastal waters. Gulf Res Rep 7:93-95

Stuck KC, Perry HM (1982) Morphological characteristics of blue crab larvae, Callinectes sapidus Rathbun, from the northern Gulf of Mexico. Completion Rep 000-011, Gulf States Mar Fish Comm, Ocean Springs, MS, USA

Stutes JP (2000) The relative importance of vertebrate and invertebrate grazing on seagrass epiphytes in the northern Gulf of Mexico: an experimental assessment. MS thesis, University of South Alabama, Mobile, AL

Thomas JL, Zimmerman RJ, Minello TJ (1990) Abundance patterns of juvenile blue crabs (Callinectes sapidus) in nursery habitats of two Texas bays. Bull Mar Sci 46: 115-125

van Montfrans J, Epifanio CE, Knott DM, Lipcius RN and 7 others (1995) Settlement of blue crab postlarvae in western Atlantic estuaries. Bull Mar Sci 57:834-854

van Montfrans J, Ryer CH, Orth RJ (2003) Substrate selection by blue crab Callinectes sapidus megalopae and first juvenile instars. Mar Ecol Prog Ser 260:209-217

Wahle RA, Steneck RS (1991) Recruitment habitats and nursery grounds of the American lobster Homarus americanus: A demographic bottleneck? Mar Ecol Prog Ser 69:231-243 Wahle RA, Steneck RS (1992) Habitat restrictions in early 
benthic life: experiments on habitat selection and in situ predation with the American lobster. J Exp Mar Biol Ecol 157:91-114

Weber JC, Epifanio CE (1996) Response of mud crab (Panopeus herbstii) megalopae to cues from adult habitat. Mar Biol 126:655-661

Weinstein MP, Brooks HA (1983) Comparative ecology of nekton residing in a tidal creek and adjacent seagrass meadow: community composition and structure. Mar Ecol Prog Ser 12:15-27

Welch JM, Rittschof D, Bullock TM, Forward RB (1997) Effects of chemical cues on settlement behavior of blue crab Callinectes sapidus postlarvae. Mar Ecol Prog Ser 154:143-153

Wennhage H (2002) Vulnerability of newly settled plaice (Pleuronectes platessa L.) to predation: effects of habitat structure and predator functional response. J Exp Mar Biol Ecol 269:129-145

Williams AB (1984) Shrimps, lobsters, and crabs of the Atlantic coast of the eastern United States, Maine to Florida. Smithsonian Institution Press, Washington, DC

Editorial responsibility: Otto Kinne (Editor-in-Chief), Oldendorf/Luhe, Germany
Williams AH, Coen LD, Stoetling MS (1990) Seasonal abundance, distribution, and habitat selection of juvenile Callinectes sapidus (Rathbun) in the northern Gulf of Mexico. J Exp Mar Biol Ecol 137:165-183

Wilson K, Heck KL Jr, Able KW (1987) Juvenile blue crab, Callinectes sapidus, survival: an evaluation of eelgrass, Zostera marina, as a refuge. Fish Bull 85:53-58

Wilson K, Able KW, Heck KL Jr (1990) Predation rates on juvenile blue crabs in estuarine nursery habitats: evidence for the importance of macroalgae (Ulva lactuca). Mar Ecol Prog Ser 58:243-251

Wolcott DL, De Vries MC (1994) Offshore megalopae of Callinectes sapidus: depth of collection, molt stage and response to estuarine cues. Mar Ecol Prog Ser 109: 157-163

Zimmerman RJ, Minello TJ, Rozas LP (2000) Salt marsh linkages to productivity of penaeid shrimps and blue crabs in the northern Gulf of Mexico. In: Weinstein MP, Kreeger DA (eds) Concepts and controversies in tidal marsh ecology. Kluwer Academic Publishers, Amsterdam

Submitted: January 31, 2005; Accepted: August 25, 2005 Proofs received from author(s): January 13, 2006 